\title{
Effect of Shot Peening on the Fatigue Properties of 40NiCrMo7 steel
}

Denisa Závodská ${ }^{1}$, Mario Guagliano $^{2}$, Otakar Bokůvka ${ }^{3}$, Libor Trško ${ }^{4}$

${ }^{1}$ University of Žilina, Faculty of Mechanical Engineering, Univerzitná 8215/1, 01026 Žilina, Slovakia. E-mail: denisa.zavodska@fstroj.uniza.sk

${ }^{2}$ Politecnico di Milano, Department of Mechanics, Via La Masa 1, 20158 Milano, Italy. E-mail: mario.guagliano@polimi.it

${ }^{3}$ University of Žilina, Faculty of Mechanical Engineering and Research Centre of University of Žilina, Univerzitná 8215/1, 01026 Žilina, Slovakia. E-mail: otakar.bokuvka@ fstroj.uniza.sk

${ }^{4}$ University of Žilina, Research Centre of University of Žilina, Univerzitná 8215/1, 01026 Žilina, Slovakia. E-mail: libor.trško@rc.uniza.sk

Fatigue properties of $40 \mathrm{NiCrMo} 7$ low alloy steel in the high cycle region were tested by rotating bending fatigue loading $\left(f=40 \mathrm{~Hz}, \mathrm{~T}=\mathbf{2 0} \pm 5^{\circ} \mathrm{C}, \mathrm{R}=\mathbf{- 1}\right)$ on notched specimens after application of shot peening surface treatment (cast steel balls with diameter of $0.43 \mathrm{~mm}$, Almen intensity $12 \mathrm{~A}$, coverage $100 \%$ and consequently the surface was re-peened with glass beads to decrease the final roughness). The compressive residual stresses created by shot peening increased the time necessary for fatigue crack initiation what in the final case increased fatigue properties. The fatigue limit $\sigma_{c}$ was higher for almost $28 \%$ in the case of notched shot peened specimens.

Keywords:40NiCrMo7 low alloy steel, fatigue lifetime, shot peening, residual stresses

\section{Acknowledgements}

The research was supported by the Slovak Research and Development Agency under the contract grant No. 1/0123/15 (45\%), project APVV-14-096 (45\%) and project Research Centre of the University of Žilina, ITMS 26220220183 (10\%).

\section{References}

[1] ARMigliATO, A. (2014). Connecting Innovations Wielton, pp. 25 - 32. Warsaw.

[2] Low alloy steel 40NiCrMo7, on-line http://www.steelforgepieces.com/Alloy-Steel/40NICRMO7.html.

[3] BAGHERIFARD, S., GHELICHI R., GUAGLIANO, M. (2012). On the shot peening surface coverage and its assessment by means of finite element simulation: A critical review and some original developments, pp. 186-194.

[4] NOVÝ, F., BOKU゚VKA, O., ŠKORÍK, V. (1991). Influence of machinning and glass bead peening on fatigue resistance of AW-6082-T6 alluminium alloy. In: Chemické Listy, Vol. 105, Issue 16, pp. 494 - 496.

[5] TRŠKO, L., BOKŮVKA, O., NOVÝ, F., GUAGLIANO, M. (2014). Effect of severe shot peening on ultra-highcycle fatigue of a low alloy steel. In: Materials and Design, pp. $103-113$.

[6] ZHANG, P., LINDEMANN, J., LEYENS, C. (2010). Shot peening on the high-strength wrought magnesium alloy AZ80 - Effect of peening media, Journal of Materials Processing Technology, Vol. 246, pp. 445-450.

[7] MARTIN, U., ALTENBERGER, I., SCHOLTES, B., KREMMER, K., OETTEL, H. (1998). Cyclic deformation and near surface microstructures of normalized shot peened steel SAE 1045. In: Materials Science and Engineering A246, pp. 69-80.

[8] NASIŁOWSKA, B., BOGDANOWICZ, Z., WOJUCKI, M. (2015). Shot peening effect on 904 L welds corrosion resistance. In: Journal of Constructional Steel Research, Vol. 115, pp. 276-282.

[9] SUBRAMANIAN, K. (1994). Surface Engineering, In: ASM Handbook, Vol. 5, pp. 278-280.

[10]MIKOVÁ, K., BAGHERIFARD, S., BOKŮVKA, O., GUAGLIANO, M., TRŠKO, L. (2013). Fatigue behavior of X70 microalloyed steel after severe shot peening. In: International Journal of Fatigue, pp. 33-42.

[11]BAGHERIFARD, S., COLOMBO, CH., GUAGLIANO, M. (2013). Application of different fatigue strength criteria to shot peened notched components. Part 1: Fracture Mechanics based approaches, pp. 1-8.

[12]BAGHERIFARD, S., GUAGLIANO, M. (2012). Fatigue behavior of a low-alloy steel with nanostructured surface obtained by severe shot peening. In: Engineering fracture Mechanics, pp. 56-68.

[13]TRŠKO, L., GUAGLIANO, M., BOKŮVKA, O., NOVÝ, F. (2014). Fatigue life of AW 7075 aluminium alloy after severe shot peening treatment with different intensities, pp. 246-252. 
[14]ZÁVODSKÁ, D., GUAGLIANO, M., BOKU゚VKA, O., TRŠKO, L. (2015). Fatigue resistance of low alloy steel after shot peening. In: 32 ${ }^{\text {nd }}$ Danubia-Adria Symposium on Advances in Experimental Mechanics, pp. 164-165. ISBN 978-80-554-1094-4. EDIS, Žilina.

[15]ZHANG, P., LINDEMANN J., LEYENS, C. (2010). Shot peening on the high-strength wrought magnesium alloy AZ80_Effect of peening media. In: Journal of Materials Processing Technology, pp. 445-450.

[16]KLANICA, O., SVOBODA E., JOSKA, Z. (2015). Changes of the surface texture after surface treatment HS6-52-5 steel. In: Manufacturing Technology, Vol. 15, pp. 47-53.

[17]DUBOVSKA, R., MAJERIK, J. (2015). Experimental investigation and analysis of cutting forces when machining X5CrNi18-10 stainless steel. In: Manufacturing Technology, Vol. 15, pp. 322-329. 